\title{
Pengaruh Konsentrasi Larutan Serbuk Siwak sebagai Pembersih pada Perendaman Akrilik Heat-Cured terhadap Kekuatan Impak
}

The Effect of Siwak Solution as Cleansing in Heat Cured Acrylic Submersion to Impact Strength

R. Setyohadi, Diwya Nugrahini, Lita Lia Amroh El Ummah

Program Studi Pendidikan Dokter Gigi, Fakultas Kedokteran Gigi, Universitas Brawijaya.

Jl. Veteran Malang 65145

Email: tiyo1958@yahoo.com

\begin{abstract}
Abstrak
Resin akrilik heat cured merupakan salah satu bahan basis gigi tiruan yang banyak digunakan. Pada perawatan gigi tiruan, pembersihan secara kimia dilakukan dengan perendaman dalam larutan pembersih. Perendaman dalam larutan pembersih dapat mempengaruhi kekuatan mekanik resin akrilik. Tujuan penelitian ini adalah untuk mengetahui pengaruh konsentrasi larutan serbuk siwak (Salvadora persica) sebagai larutan pembersih pada perendaman lempeng resin akrilik heat cured terhadap kekuatan impak. Penelitian ini merupakan penelitian eksperimental laboratoris menggunakan lempeng resin akrilik heat cured sebagai sampel sebanyak 24 buah yang terbagi menjadi 4 kelompok. Kelompok pertama sebagai kelompok kontrol dengan rendaman aquades. Kelompok kedua, ketiga, dan keempat menggunakan rendaman larutan serbuk siwak dengan konsentrasi yang didapat dari penelitian pendahuluan, yaitu $25 \mathrm{gr} \%, 37,5 \mathrm{gr} \%$, dan $50 \mathrm{gr} \%$. Lempeng resin akrilik direndam sesuai kelompok perlakuan selama 7 hari, kemudian diukur kekuatan impaknya. Hasil uji Anova one way menunjukkan adanya pengaruh yang signifikan pada kelompok perlakuan dengan $p=0,000(p<$ $0,05)$. Kesimpulan dari penelitian ini adalah terdapat pengaruh konsentrasi larutan serbuk siwak (Salvadora persica) pada perendaman lempeng resin akrilik heat cured terhadap kekuatan impak.
\end{abstract}

Kata kunci: resin akrilik, siwak, kekuatan impak. 


\begin{abstract}
Heat cured acrylic resin is one of the denture based materials which mostly used. Chemical cleaning of denture is done by soaking in cleaning solution. Soaking in cleaning solution can affect strength of acrylic resin mechanic. The objective of this study is to know the effect of siwak (Salvadora persica) powder solution concentrate in heat cured acrylic resin plate soak to the impact strength. This study is experimental laboratory used in 24 heat cured acrylic resin plate as the samples which divided into four groups. First group is a control group with aquades soaks, and the others use the soak of siwak powder solution with concentration found from the previous study, which is $25 \mathrm{gr} \%, 37,5 \mathrm{gr} \%$, and $50 \mathrm{gr} \%$. Heat cured acrylic resin is soaked until 7 days based on the group. Then, measured its impact strength. The result study of Anova one way shows the effect in group with $p=0,000(p<0,05)$. The conclusion of this study is there is an effect of siwak (Salvadora persica) powder solution concentrate in heat cured acrylic resin plate soak to the impact strength.
\end{abstract}

Keywords: acrylic resin, siwak, impact strength. 


\section{PENDAHULUAN}

Resin akrilik sampai saat ini masih merupakan pilihan untuk pembuatan basis gigi tiruan lepasan (denture) oleh karena harganya relatif murah, mudah direparasi, proses pembuatannya mudah, menggunakan peralatan sederhana, warna stabil, dan mudah dipulas. ${ }^{1}$

Dalam perawatannya, pembersihan gigi tiruan lepasan dilakukan dengan dua cara, yaitu pembersihan mekanik atau dengan menggunakan sikat gigi, dan pembersihan kimia dengan perendaman dalam larutan pembersih (cleaning solution). ${ }^{2}$

Kayu siwak (Salvadora Persica) telah dipercayai mempunyai efek atau mengandung ekstrak yang baik di dalam menjaga kebersihan gigi dan gingiva. Komposisi siwak memiliki efek antibakteri, yaitu trymetylamin, tannin, chloride, nitrat, sulfat, saponins, sterols, salvadorine, dan fluoride. ${ }^{3}$ Dalam sebuah penelitian mengenai efek fungisidal larutan siwak (Salvadora persica) terhadap Candida albicans pada basis akrilik, diketahui konsentrasi yang paling banyak dan perendaman yang paling lama lebih efektif dalam mereduksi koloni Candida albicans. ${ }^{4}$ Namun pemakaian bahan disinfektan tertentu ternyata mempunyai efek samping terhadap basis gigi tiruan akrilik bahkan juga pada pemakai disinfektan itu sendiri. Dari penelitian yang pernah dilakukan ternyata bahan yang digunakan sebagai pembersih maupun desinfektan dengan cara merendam basis akrilik gigi tiruan mempunyai pengaruh terhadap sifat fisik dan morfologis gigi tiruan. ${ }^{4}$ Salah satu sifat tersebut adalah kekuatan impak. Kekuatan impak menurut Anderson ${ }^{5}$ yaitu daya tahan suatu bahan agar tidak patah bila mendapat daya yang besar dan tiba-tiba dalam bentuk tension dan compression.

\section{TUJUAN}

Penelitian ini bertujuan untuk mengetahu pengaruh konsentrasi larutan serbuk siwak sebagai larutan pembersih pada perendaman lempeng resin akrilik heat cured terhadap kekuatan impak.

\section{METODE PENELITIAN}

Desain penelitian yang digunakan adalah eksperimental laboratoris. Sampel yang digunakan berupa lempeng resin akrilik heat cured dengan ukuran $65 \mathrm{~mm} \times 10 \mathrm{~mm} \times$ $2,5 \mathrm{~mm}$ yang berjumlah 24 . Kriteria sampel yaitu sesuai ukuran $(65 \mathrm{~mm} \times 10 \mathrm{~mm} \times 2,5$ $\mathrm{mm})$, permukaan rata dan halus, serta tidak porus. Penelitian dilaksanakan di Laboratorium Desain, Jurusan Teknik Mesin, Fakultas Teknologi Industri Institut Teknologi Sepuluh Nopember, Surabaya.

Bahan yang digunakan dalam penelitian ini adalah resin akrilik heat-cured berwarna pink (sewarna gingiva), vaselin, gips keras tipe II dan gips lunak tipe I, kertas gosok, cold mould seal (separator), plastik celophan, serbuk siwak (Salvadora persica), dan aquades steril. Alat yang digunakan adalah master model terbuat dari logam ukuran $65 \mathrm{~mm} \times 10 \mathrm{~mm} \times 2,5 \mathrm{~mm}$, bowl dan spatula, gelas ukur dan spatula pengaduk, pisau gips, vibrator, alat pengaduk akrilik dan pot porselen, kuas, kuvet dan press, jangka sorong, gelas untuk merendam, benang untuk menggantung, press hidrolis, straight handpiece, fraser, chip blower dan tissue, blender, dan timbangan elektrik. Cara pembuatan sampel yaitu seluruh permukaan kuvet bagian dalam dan spesimen logam 
diulasi dengan vaselin secukupnya. Gips lunak diaduk di atas vibrator dengan perbandingan sesuai petunjuk pabrik. Gips lunak dituangkan ke dalam kuvet sampai setengah tinggi kuvet. Setelah gips lunak mengeras (setting), gips keras diaduk di atas vibrator dan dituangkan di atas gips lunak sampai hampir memenuhi kuvet. Spesimen dari logam diletakkan di tengah kuvet dalam adonan gips tersebut dalam posisi mendatar sampai tertanam separuh bagian. Masing-masing kuvet diisi 1 buah spesimen. Setelah setting, permukaan gips keras diulasi dengan vaselin. Memasang kuvet lawan. Mengaduk gips keras di atas vibrator lalu dituangkan ke dalam kuvet sampai setengah tinggi kuvet. Setelah setting, gips lunak diaduk dan dituangkan di atas gips keras sampai memenuhi kuvet. Setelah itu kuvet ditutup dan pres dengan alat pres. Setelah gips mengeras, kuvet dibuka, spesimen logam diambil. Seluruh permukaan gips diulasi dengan CMS dengan menggunakan kuas, merata ke satu arah agar tidak menggumpal. Dibiarkan hingga kering. Bubuk dan cairan resin akrilik disiapkan sesuai petunjuk pabrik, diaduk dalam pot porselen. Setelah adonan menjadi dough stage, adonan diletakkan dalam cetakan lalu ditutup dengan plastik celophan. Kuvet ditutup dan ditekan dengan pres hidrolis perlahan-lahan. Kuvet dibuka, dan kelebihan akrilik dipotong. Permukaan akrilik diulasi dengan sedikit monomer. Kuvet ditutup kembali lalu dipres sampai tidak ada kelebihan akrilik. Kuvet yang sudah terisi resin akrilik heat cured direndam dalam air dengan temperatur kamar selama \pm 30 menit. Setelah itu, proses perebusan akrilik \pm 45 menit mulai dari air mendidih. Kemudian api dimatikan dan dibiarkan sampai dingin, setelah itu dilepas dari pres. Akrilik diambil, kelebihannya dipotong dengan fraser kemudian dihaluskan dengan kertas gosok di bawah air mengalir dengan gerakan melingkar sampai sesuai dengan ukuran lempeng yang diinginkan, lalu dikeringkan. Cara pembuatan serbuk siwak yaitu Batang kayu siwak dipotong-potong tipis, lalu diblender, maka diperoleh serbuk siwak yang halus. Selanjutnya, dilanjutkan dengan proses pelarutan dalam aquades. Konsentrasi larutan didapatkan dari penelitian pendahuluan. Perendaman lempeng resin akrilik pada penelitian pendahuluan dilakukan dengan larutan serbuk siwak $5 \mathrm{gram} / 250 \mathrm{ml}, 10$ gram/250 ml, $15 \mathrm{gram} / 250 \mathrm{ml}$, dan 20 gram/250 ml. Hasil uji impak menunjukkan pada perendaman lempeng resin akrilik dalam larutan serbuk siwak $5 \mathrm{gram} / 250 \mathrm{ml}$ belum terdapat pengaruh kekuatan impak yang bermakna dengan membandingkan kekuatan impak pada lempeng yang direndam dalam aquades sebagai kelompok kontrol. Pengenceran dilkukan padal 10 gram serbuk siwak dilarutkan dalam $250 \mathrm{ml}$ aquades steril, setara dengan konsentrasi $25 \mathrm{gr} / 100 \mathrm{ml}$ ( $25 \mathrm{gr}$ \%), 15 gram serbuk siwak dilarutkan dalam $250 \mathrm{ml}$ aquades steril, setara dengan konsentrasi 37,5gr/100ml (37,5 gr\%), dan 20 gram serbuk siwak dilarutkan dalam $250 \mathrm{ml}$ aquades steril, setara dengan konsentrasi $50 \mathrm{gr} / 100 \mathrm{ml} \quad$ (50 gr\%). Sebelum diberi perlakuan, semua sampel direndam dalam aquades selama $2 \times 24$ jam untuk mencapai tingkat kejenuhan yang maksimal sehingga keadaannya diasumsikan sama dengan kondisi gigi tiruan dalam rongga mulut. Lempeng akrilik heat cured sebanyak 24 spesimen direndam dengan posisi tergantung agar seluruh permukaan akrilik tidak menempel pada permukaan dinding gelas 
perendam yang memungkinkan berpengaruh pada permukaan lempeng resin akrilik. Perendaman dilakukan per satu spesimen setiap bahan perendam. Dari 24 sampel dibagi menjadi 4 kelompok yang masingmasing terdiri dari 6 sampel. Kelompok I (kelompok kontrol) direndam dalam aquades selama 7 hari, kelompok II direndam dalam larutan serbuk siwak 25 gr\% selama 7 hari, kelompok III direndam dalam larutan serbuk siwak 37,5 gr\% selama 7 hari, dan kelompok IV direndam dalam larutan serbuk siwak $50 \mathrm{gr}$ $\%$ selama 7 hari. Setelah proses perendaman, sampel dibersihkan dari sisa bahan perendam kemudian dikeringkan. Setelah itu, dilakukan pengukuran kekuatan impak dan dicatat hasilnya.

Alat yang digunakan untuk mengukur kekuatan impak adalah Mini impact testing machine dengan charphy method. Pengujian ini dilakukan pada suhu kamar. Test piece diletakkan pada landasan (anvi), dinaikkan pada setinggi $h$ atau sebesar sudut a (pada pengukuran ini sudut a diambil $90^{\circ}$ ). Kemudian mengatur posisi jarum petunjuk skala pada posisi nol. Bandul dilepas sehingga memukul test piece, bandul masih akan berayun setinggi $h$ atau sebesar sudut $\beta$. Mengamati dan mencatat perubahan sudul yang terjadi. Selanjutnya dilakukan penghitungan dengan rumus.

Rumus kekuatan impak:

$K I=\underline{W} \cdot L(\cos \beta-\cos a)(g r a m / c m)$

\section{A}

Keterangan rumus:

$\mathrm{KI}=$ Kekuatan impak

$\mathrm{W}=$ berat bandul + berat logam (750 gram)

$\mathrm{L}=$ panjang lengan $(332,6 \mathrm{~cm})$

$a=$ sudut awal bandul sebelum diayun $\left(90^{\circ}\right)$

$\beta=$ sudut awal bandul sesudah diayun
$A=$ luas penampang batang $u j i\left(\mathrm{~cm}^{2}\right)$

\section{HASIL PENELITIAN}

Pada gambar 1 terlihat adanya penurunan kekuatan impak pada lempeng resin akrilik yang direndam konsentrasi larutan serbuk siwak 25 gr\%, 37,5 gr\%, dan konsentrasi 50 gr\% dibandingkan dengan kelompok kontrol (aquades).

Untuk mengetahui perbedaan besar kekuatan impak lempeng resin akrilik heat cured oleh karena variasi konsentrasi larutan serbuk siwak (Salvadora persica), maka digunakan metode statistik dengan pola distribusi normal dan homogen, yaitu Anova one way seperti pada dan uji korelasi Tukey HSD.

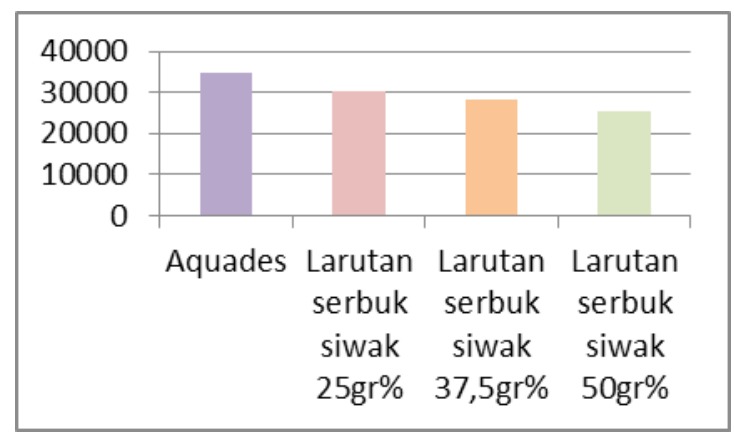

Gambar 1. Grafik Rerata Uji Impak pada Kelompok Perlakuan

Dari hasil uji Anova one way, dapat disimpulkan bahwa pemberian konsentrasi larutan yang berbeda telah memberikan pengaruh yang signifikan terhadap kekuatan impak dengan nilaoi $p=0,00(p<0,05)$. Hasil uji Tukey HSD menunjukkan terdapat perbedaan bermakna pada kelompok perendaman dalam aquades dengan kelompok perendaman dalam larutan serbuk siwak (25 gr\%, 37,5 gr\%, dan 50 gr\%). Pada perbandingan antara kelompok rendaman larutan serbuk siwak $25 \mathrm{gr} \%$ dengan kelompok rendaman larutan serbuk siwak 50 gr\%, didapatkan perbedaan kekuatan impak yang bermakna. Sedangkan pada perbandingan antara kelompok rendaman 
larutan serbuk siwak 37,5 gr\% dengan kelompok rendaman larutan serbuk siwak 25 gr\% dan 50 gr\%, tidak didapatkan perbedaan kekuatan impak yang bermakna.

\section{PEMBAHASAN}

Larutan serbuk siwak pada penelitian ini digunakan sebagai larutan pembersih gigi tiruan berbahan resin akrilik heat-curing. Hal ini karena kayu siwak memiliki beberapa komponen zat yang efektif sebagai antibakteri, ${ }^{6}$ dan sebagai fungisidal. ${ }^{4}$

Penggunaan kayu siwak telah dikenal semenjak berabad-abad lalu, terutama oleh bangsa Arab kuno yang hingga sekarang masih digunakan sebagai alat kebersihan mulut. Faktor sosial dan agama menjadi pendorong utama penggunaan kayu siwak terutama bagi masyarakat muslim. ${ }^{6}$ Dalam ranah hukum Islam, penggunaan kayu ini sangat dianjurkan, seperti dalam sebuah sabda Nabi Muhammad saw, "Apabila sekiranya tidak memberatkan umatku, akan aku perintahkan mereka bersiwak sebelum berwudhu" (dalam hadits lain: "....bersiwak sebelum menegakkan sholat"). ${ }^{7}$

Terdapat dua kelompok perlakuan pada penelitian ini, yaitu kelompok kontrol dan kelompok perlakuan dengan berbagai macam konsentrasi. Kelompok kontrol dilakukan dengan cara merendam lempeng resin akrilik dalam aquades selama 7 hari. Kelompok perlakuan dibagi menjadi tiga kelompok konsentrasi, yaitu kelompok konsentrasi larutan serbuk siwak $25 \mathrm{gr} \%$, 37,5 gr\%, dan $50 \mathrm{gr} \%$. Lempeng resin akrilik direndam pada masing-masing kelompok konsentrasi selama 7 hari.

Berdasarkan hasil penelitian yang telah dilakukan mengenai pengaruh konsentrasi larutan serbuk siwak (Salvadora persica) pada perendaman lempeng resin akrilik heat-cured terhadap kekuatan impak menujukkan semakin tinggi konsentrasi atau kepekatannya, maka semakin terjadi penurunan kekuatan impak resin akrilik. Penurunan kekuatan impak disebabkan proses kejenuhan oleh karena penyerapan air dari resin akrilik heat-cured. Penyerapan air terjadi secara difusi. Proses difusi merupakan migrasi atau berpindahnya suatu substansi melalui rongga. Molekul air dapat menembus kepadatan polymethilmethacrylate atau resin akrilik dan menempati posisi di antara rantai polimer yang mengakibatkan rantai polimer terdesak dan memisah. ${ }^{8}$ Resin akrilik yang direndam dalam larutan serbuk siwak akan terjadi ikatan fisik sekunder yaitu absorbsi karena adanya molekul yang polar yaitu gugus $\mathrm{COOH}$ (gugus karboksil) pada resin akrilik yang mudah sekali bereaksi dengan air. Air akan mengisi liang renik (porositas) pada resin akrilik. ${ }^{9}$

Penurunan kekuatan impak resin akrilik heatcured juga bisa disebabkan karena komponen yang terkandung dalam siwak. Kekuatan fisik resin akrilik dapat dipengaruhi oleh beberapa zat seperti benzena, metanol, fenol dan lainlain. ${ }^{10}$ Komponen dalam siwak yang bisa mempengaruhi kekuatan impak resik akrilik adalah tannin dan chlorida. Tannin merupakan bahan yang bersifat antiseptik yang dapat mematikan atau mencegah pertumbuhan mikroorganisme patogen. ${ }^{11}$ Daya antiseptik tannin disebabkan oleh adanya gugus pirogalol dan gugus galoil yang merupakan gugus fenol. ${ }^{12}$ Fenol apabila kontak dengan resin akrilik menunjukkan peningkatan berat oleh karena penyerapan air dan pengaruh kimia pada morfologi 
permukaan resin akrilik. Senyawa fenol dapat diserap oleh permukaan resin akrilik dan menyebabkan permukaan resin akrilik menjadi mengembang dan lunak. Fenol yang terkandung mengalami penetrasi ke dalam lempeng resin akrilik dan terjadi pemutusan rantai panjang polimer resin akrilik, yang mengakibatkan ikatan antar molekul menurun sehingga menurunkan kekuatan resin akrilik termasuk kekuatan impak. ${ }^{13}$ Chlorida yang terkandung dalam siwak berfungsi menghambat pertumbuhan kalkulus dan membantu menghilangkan stain. Chlorida dapat mempengaruhi ikatan rantai polimer. Semakin tinggi kadar chlorida, akan semakin tinggi oksidator yang dapat mempengaruhi bahan-bahan reduktor dalam polimer. Ikatan rangkap $\mathrm{C}=\mathrm{C}, \mathrm{C}=\mathrm{O}$, atau $\mathrm{C}-\mathrm{OCH}_{3}$ pada polymethilmethacrylat akan terputus, dalam artian rantai polimer menjadi pendek. ${ }^{9}$

Kekuatan impak minimal basis gigi tiruan resin akrilik heat-cured adalah $10 \mathrm{~cm} \mathrm{~kg} / \mathrm{cm}^{2} .{ }^{14}$ Hasil perendaman resin akrilik heat-cured dalam larutan serbuk siwak 50 gr\% selama 7 hari menunjukkan rata-rata kekuatan impak sebesar 25,537 cm kg/ $\mathrm{cm}^{2}$. Nilai kekuatan impak terendah pada penelitian ini lebih besar dibanding nilai kekuatan impak minimal yang disarankan. Oleh karena itu, pemakaian larutan serbuk siwak sebagai bahan pembersih gigi tiruan dapat diterima.

\section{KESIMPULAN}

Terdapat pengaruh konsentrasi larutan serbuk siwak (Salvadora persica) pada perendaman lempeng resin akrilik heat cured terhadap kekuatan impak. Kekuatan impak resin akrilik yang telah direndam dalam aquades selama 7 hari rata-rata sebesar 34666,898 gram/cm. Kekuatan impak resin akrilik yang telah direndam dalam larutan serbuk siwak dengan konsentrasi 25 gr\% selama 7 hari rata-rata sebesar 30270,092 gram/cm . Kekuatan impak resin akrilik yang telah direndam dalam serbuk siwak dengan konsentrasi 37,5 gr\% selama 7 hari rata-rata sebesar 28327,043 gram/cm. Kekuatan impak resin akrilik yang telah direndam dalam serbuk siwak dengan konsentrasi 50 gr\% selama 7 hari rata-rata sebesar 25537,859 gram/cm. Semakin besar konsentrasi larutan serbuk siwak yang digunakan dalam perendaman resin akrilik, maka semakin kecil kekuatan impak resin.

\section{DAFTAR PUSTAKA}

1. Nirwana I. 2005. Kekuatan Transversa Resin Akrilik Hybrid setelah Penambahan Glass Fiber dengan Metode Berbeda. Majalah Kedokteran Gigi. 38 (1): 16-19.

2. Budtz-Jorgensen E. 1979. Materials and Methods for Cleaning Dentures, Journal Prosthetic Dentistry. 42 (6): 619-623.

3. Mutiadewi E. 2004. Efek Penggunaan Siwak pada Gigi dan Gingiva. Skripsi. Tidak diterbitkan, Fakultas Kedokteran Gigi Universitas Sumatera Utara, Medan. hal. 15.

4. Yogiartono M, Widjoseno TM. 2001. Efek Fungisid Larutan Salvadora persica terhadap Candida albicans pada Basis Akrilik. Majalah Kedokteran Gigi. 34 (2): 91-95.

5. Anderson JN. 1982. Applied Dental Materials, $5^{\text {th }}$ Ed., Blackwell Scientific Publications, Edinburgh, p. 247-267.

6. Zaenab. 2004 Uji Antibakteri Siwak (Salvadora persica) terhadap Stertococcus mutans dan Bacteroides melaninogenicus. Makara Kesehatan. 8 (2): 37-40.

7. Basyarahil, H. 1993. Peranan Miswak (Chewing-Stick) terhadap Kesehatan Gigi 
dan Mulut. Majalah Kedokteran Gigi. 32 (1): 21-23.

8. Anusavice, Kenneth J. 2001. Phillips' Science of Dental Materials, $9^{\text {th }}$ ed., W.B. Saunders Company, Saint Louis, p.198

9. Firman, A. 2009. Pengaruh Konsentrasi Ekstrak Siwak (Salvadora persica) pada Perendaman Lempeng Resin Akrilik terhadap Kekerasan Permukaan. Skripsi. Tidak diterbitkan, Fakultas Kedokteran Gigi Universitas Airlangga, Surabaya. hal 35-40.

10.Munadziroh E, Indrasari M. 2000. Kekuatan Impak Resin Akrilik Heat-Cured dan Self-Cured setelah Direndam Larutan Teh Hitam. Majalah Kedokteran Gigi. 33 (3): 95-98.

11.Dorland WAN. 2005. Kamus Kedokteran Dorland WA, Edisi 29, Huriawati Hartanto, dkk (penerjemah), EGC, Jakarta, hal. 1069.

12.Yasin, M. 2007. Uji Efek Antibakteri Ekstrak Serbuk Kayu Siwak (Salvadora persica) terhadap Pertumbuhan Streptococcus sanguis pada Penderita Reccurent Aphthous Stomatitis dengan Broth Dillution Methods. Skripsi. Tidak diterbitkan, Fakultas Kedokteran Gigi Universitas Airlangga, Surabaya. hal. 52.

13.Umayasari, S. 2010. Perendaman Resin Akrilik dengan Ekstrak Serbuk Kayu Siwak (Salvadora persica) terhadap Pertumbuhan Mikroorganisme Rongga Mulut. Skripsi. Tidak diterbitkan, Fakultas Kedokteran Gigi Universitas Airlangga, Surabaya. hal. 45-8 14.Craig RG, Powers JM and Wataha JC. 2004. Properties andipulation dental materials, $8^{\text {th }}$ Ed., Mosby Inc, Saint Louis, p. $124-6,271-92$ 